\title{
肥満が腹腔鏡下子宮体癌手術に及ぼす影響の検討
}

慶應義塾大学医学部産科婦人科学教室

平野卓朗、片岡史夫、南木佳子、吉浜智子、真壁 健、 坂井健良、山上 亘、林 茂德、野村弘行、青木大輔

\section{Effect of obesity on operative outcomes of laparoscopic surgery in patients with early stage endometrial cancer}

Takuro Hirano, Fumio Kataoka, Yoshiko Nanki, Tomoko Yoshihama, Takeshi Makabe, Kensuke Sakai, Wataru Yamagami, Shigenori Hayashi, Hiroyuki Nomura, Daisuke Aoki

Keio University School of Medicine, Department of Obstetrics \& Gynecology

\begin{abstract}
Objective: The aim of this study was to clarify operative outcomes after laparoscopic surgery in patients with obesity diagnosed with early stage endometrial cancer.

Design: We retrospectively analyzed the medical records of 150 patients treated at our hospital between 2012 and 2016 to determine the prevalence of obesity and surgical outcomes. Patients were divided into the non-pelvic lymphadenectomy (PLN-) and pelvic lymphadenectomy (PLN+) groups. We compared surgical outcomes between patients with and without obesity in each group.

Results: We observed that 45 of the 150 patients were diagnosed with obesity (body mass index $\geq 25 \mathrm{~kg} / \mathrm{m}^{2}$ ). No significant differences were observed in operative time, estimated blood loss, and duration of postoperative hospitalization between patients with and without obesity in the PLN- group. The operative time was longer ( $p=0.001)$ and the number of lymph nodes removed was higher $(\mathrm{p}=0.001)$ in patients with obesity in the PLN+ group. No significant differences were observed in estimated blood loss and the duration of postoperative hospitalization between patients with and without obesity in the PLN+ group. Intra- and postoperative complication rates were similar between patients with and without obesity ( $6.7 \%$ vs. $7.6 \%)$.

Conclusion: We conclude that laparoscopy can be safely performed for early stage endometrial cancer in patients with and without obesity.
\end{abstract}

Keywords: early stage endometrial cancer, laparoscopic surgery, patient with obesity

\section{【緒言】}

2014年 4 月より国内において早期子宮体癌に対 する腹腔鏡下手術が保険収載され、今後肥満子宮 体癌患者に対する腹腔鏡下手術件数は増加するこ とが予想される。肥満患者に対し術中や術後の合 併症を減少させる目的で、腹腔鏡下手術は低侵襲 であり有用であると考えられる一方で、大腸癌領 域においては非肥満患者に比べ肥満患者では腹腔 鏡下手術における縫合不全や呼吸器系の合併症が 増加する等の報告もされている1)。そこで今回
我々は腹腔鏡下子宮体癌手術における肥満の影響 を検討することを目的とした。

\section{【対象と方法】}

対象は2012年 4 月から2016年12月までに当院に て、子宮内膜組織診もしくは子宮内膜全面搔爬で 類内膜癌 $\mathrm{G} 1 も し く は \mathrm{G} 2$ と診断され、骨盤MRIで 子宮筋層への浸潤が $1 / 2$ 未満であり、体幹部CTで 子宮外病変を認めない子宮体癌 IA 期相当 （FIGO2008）の術前診断のもと、腹腔鏡下子宮体 癌手術を施行した162症例である。以下に当院に 
おける腹腔鏡子宮体癌手術の手順を示す。パワー デバイスに関しては術者により異なり、PROBE PLUS $^{\mathrm{TM}}$ (Ethicon社)、HARMONIC $\mathrm{ACE}^{\mathrm{TM}}+$ (Ethicon社)、BiClamp ${ }^{\mathrm{TM}}$ (ELBE社)、 Ligasure $^{\mathrm{TM}}$ (Medtronic社) 等を使用している。トロッカー の配置はダイヤモンド法とし、子宮への手術操作 前に経卵管的な腫瘍の腹腔内への飛散を防ぐ目的 で両側卵管を凝固している。また、子宮マニピュ レーターに関しては原則として使用しておらず、 臍横にトロッカーを挿入し同部位より鉗子を挿入 し子宮を搽引している。次に子宮摘出を行うが、 後腹膜腔を展開し尿管と子宮動脈の走行を確認 し、子宮動脈をなるべく骨盤側で凝固し、筋膜外 術式で胵壁を $5 \mathrm{~mm}$ 程度切除し子宮を摘出してい る。術中に摘出した子宮内腔に病変を認めた場合 は迅速病理診断を行い、類内膜癌 $\mathrm{G} 2$ もしくは筋 層浸潤を認めた場合には骨盤リンパ節郭清を追加 し、その際は手術終了時にダグラス窩にドレーン を留置している。また、類内膜癌 $\mathrm{G} 3$ もしくは特 殊組織型、 $1 / 2$ 以上の筋層浸潤や肉眼的に子宮外 進展を認めた場合は開腹手術へ移行し傍大動脈リ ンパ節郭清と大網切除を追加している。術中は深 部静脈血栓症を防ぐ目的で、使用禁忌に該当しな い症例に対しては両下腿に逐次型空気圧式マッサ ージ器を装着している。また高度肥満患者には抗 凝固療法として、術後24時間経過後からエノキサ パリンナトリウム 1 回2000IUを、12時間毎に 1 日 2 回連日皮下注射している。結果的に、術中迅 速病理診断の結果で開腹手術に移行した12例を除 いた150例を解析の対象とした。術後治療に関し ては術後再発中高リスクに該当する症例には原則 的に術後化学療法を行った。解析対象のうち、骨 盤リンパ節郭清を施行しなかった群（以下PLN （－）群）と骨盤リンパ節郭清を施行した群（以 下PLN（+）群）に分類し、それぞれの群の中で 非肥満症例と肥満症例に打ける患者背景 (年齢、 未産婦数、糖尿病ならびに高血圧の頻度、病理組 織型、手術進行期（FIGO 2008））および治療成 績（手術時間、推定出血量、術後入院期間、リン パ節郭清群では摘出リンパ節個数)、術中および 術後合併症の内訳およびその頻度、術後治療の有 無、無増悪生存割合ならびに全生存割合について 後方視的に比較検討した。また、2012年より 2017 年までに当院で開腹手術を施行した子宮体癌症例 49例の摘出リンパ節個数を、非肥満症例と肥満症 例で比較を行った。肥満の定義に関しては肥満症 診療ガイドライン $2016 よ り B M I ~ 25 \mathrm{~kg} / \mathrm{m}^{2}$ 以上を肥
満症例と定義した ${ }^{2)}$ 。また術中術後合併症に関し ては、術中輸血以外の項目はCTCAE.ver4.0に準 拠し、Grade2以上を合併症ありとした ${ }^{3)}$ 。統計学 的解析にはIBM SPSS Statistics $25^{\mathrm{TM}}$ (IBM社) を使用し、統計学的手法としてMann-Whitneyの U検定、カイ二乗検定を用い、 $p<0.05$ を統計学的 に有意差ありとした。なお、本研究は慶應義塾大 学医学部倫理審査委員会より承認を受けた。(承 認番号20110237)

\section{【結 果】}

初めにPLN (+) 群とPLN（-）群における患 者背景を表 1 に示す。全症例においてBMI $25 \mathrm{~kg} /$ $\mathrm{m}^{2}$ 未満の症例は105例 (70\%)、BMI $25 \mathrm{~kg} / \mathrm{m}^{2}$ 以 上は 45 例（30\%）認め、またBMI $30 \mathrm{~kg} / \mathrm{m}^{2}$ 以上 35 $\mathrm{kg} / \mathrm{m}^{2}$ 未満を 20 例 (13.3\%) に認め、さらにBMI $35 \mathrm{~kg} / \mathrm{m}^{2}$ 以上を 5 例 (3.3\%) に認めた。PLN (-) 群とPLN (+) 群いずれにおいても非肥満症例と 肥満症例間で年齢、未産婦割合、高血圧の頻度、 病理組織型、手術進行期（FIGO2008）の内訳に 有意差は認めなかったが、糖尿病の頻度は肥満症 例で有意に高かった。

次にPLN（-）群での治療成績を表 2 に示す。 非肥満症例と肥満症例において手術時間、術中出 血量、術後在院日数いずれも有意差を認めなかっ た。

次にPLN (+) 群での治療成績を表 3 に示す。 非肥満症例に比して肥満症例では手術時間が有意 に延長していたが、術中出血量、術後在院日数は 有意差を認めなかった。また、摘出リンパ節個数 は非肥満症例に比して肥満症例で有意に摘出数が 多かった。一方で、過去の開腹手術における摘出 リンパ節数に関しては、肥満症例（10例） $36 \pm 12$ 個、非肥満症例（39例） $42 \pm 14$ 個であり、摘出リ ンパ節個数に有意差は認めなかった。

次にPLN (-) 群拧よびPLN (+) 群における、 非肥満症例と肥満症例の術中 ・ 術後合併症の発生 数を表 4 に示す。合併症の発生率は非肥満症例で $7.6 \%$ 、肥満症例で $6.7 \%$ でり、発生頻度に有意差 は認めず、特に肥満症例において血栓症等の致死 的な合併症は認めなかった。

最後に非肥満症例と肥満症例の無増悪生存割合 および全生存割合を図 1 に示す。非肥満症例と肥 満症例の 5 年無増悪生存割合はそれぞれ $92.8 \%$ と 100\%（図1A）、5 年全生存割合はそれぞれ $98.5 \%$ と100\%（図1B）であり有意差は認めなかった。 
表1. PLN (-) 群およびPLN (+) 群における患者背景

\begin{tabular}{|c|c|c|c|c|c|c|}
\hline & \multicolumn{2}{|c|}{ PLN- $(n=75)$} & \multirow[t]{2}{*}{ P值 } & \multicolumn{2}{|c|}{$\mathrm{PLN}+(\mathrm{n}=75)$} & \multirow[t]{2}{*}{ P值 } \\
\hline & $\begin{array}{c}\text { 非肥满泟例 } \\
(n=51) \\
\end{array}$ & $\begin{array}{c}\begin{array}{c}\text { 肥满症例 } \\
(n=24)\end{array} \\
\end{array}$ & & $\begin{array}{c}\text { 非肥满泟例 } \\
(n=54)\end{array}$ & $\begin{array}{l}\text { 肥满症例 } \\
(n=21) \\
\end{array}$ & \\
\hline 年齢(㒼) & $52(35-74)$ & $53(38-87)$ & n.s & $54(34-83)$ & $50(33-70)$ & n.s \\
\hline $\mathrm{BMI}\left(\mathrm{kg} / \mathrm{m}^{2}\right)$ & $\begin{array}{c}21.0 \\
(15.9-23.7) \\
\end{array}$ & $\begin{array}{c}29.9 \\
(25.2-37.2) \\
\end{array}$ & $<0.001$ & $\begin{array}{c}20.6 \\
(16.5-24.8) \\
\end{array}$ & $\begin{array}{c}28.4 \\
(25.0-39.8) \\
\end{array}$ & $<0.001$ \\
\hline 未厓㛿数(\%) & $21(41)$ & $12(50)$ & n.s & $25(46)$ & $11(52)$ & n.s \\
\hline 糖尿病 $(\%)$ & 2(3.9) & $5(20.8)$ & 0.031 & 1(1.9) & 4(19) & 0.02 \\
\hline 高血压 $(\%)$ & $8(15.7)$ & $7(29.2)$ & n.s & $9(16.7)$ & $6(28.6)$ & n.s \\
\hline $\begin{array}{l}\text { 手術進行期 } \\
\text { (FIGO 2008) }\end{array}$ & & & n.s & & & n.s \\
\hline IA期 & 49 & 24 & & 48 & 20 & \\
\hline IB期 & 0 & 0 & & 3 & 0 & \\
\hline 川I期 & 1 & 0 & & 1 & 0 & \\
\hline III期 & 1 & 0 & & 2 & 1 & \\
\hline 病理組織型 & & & n.s & & & n.s \\
\hline 類内膜癌G1 & 43 & 20 & & 30 & 13 & \\
\hline 類内膜癌G2 & 6 & 3 & & 20 & 8 & \\
\hline $\begin{array}{l}\text { 類内膜癌G3+ } \\
\text { 特殊織型 }\end{array}$ & 2 & 1 & & 4 & 0 & \\
\hline
\end{tabular}

年齢, BMIはいずれも中央値（最小值-最大値）を示した

表2. PLN (-) 群における手術成績と術後治療, 治療予後

\begin{tabular}{|c|c|c|c|}
\hline & 非肥満症例 $(n=51)$ & 肥満症例 $(n=24)$ & P値 \\
\hline 手術時間(分) & $176(96-331)$ & $177.5(97-308)$ & n.s \\
\hline 推定出血量 $(m L)$ & $75(10-350)$ & $100(10-450)$ & $\mathrm{n}, \mathrm{s}$ \\
\hline 衍後入院期間(日) & $5(3-7)$ & $5(4-13)$ & n.s \\
\hline 術後追加治療 & & & n.s \\
\hline 化学療法 & 6 & 0 & \\
\hline なし & 45 & 24 & \\
\hline 再発者数(人) & 1 & 0 & n.s \\
\hline 死亡者数 (入) & 1 & 0 & n.s \\
\hline 経過䚁察期問(月) & $41(2-76)$ & $29(1-74)$ & $\mathrm{n}, \mathrm{s}$ \\
\hline
\end{tabular}

手術時間, 推定出血量, 術後入院期間, 経過観察期間はいずれも中央値（最小値-最大値） を示した

\section{【考察】}

当院では2012年より当時先進医療であった腹腔 鏡下子宮体癌手術を早期に導入し積極的に早期子 宮体癌に対し腹腔鏡下手術を行ってきた。その結 果単施設で150例の手術例の蓄積に至り、また高 度肥満症例にも腹腔鏡手術を施行したことで、肥 満が手術に及ぼす影響について検討することが可 能となった。

肥満子宮体癌患者の腹腔鏡下子宮体癌手術の治 療成績に関して、Min-Hyunらの報告では BMI $28 \mathrm{~kg} / \mathrm{m}^{2}$ 以上の肥満患者は非肥満患者と比較
乙周術期合併症の発生率、手術時間、術中出血量、 術後在院日数、摘出リンパ節数は同等であったと している。国内において寺井らの報告では5)、 BMI $30 \mathrm{~kg} / \mathrm{m}^{2}$ 以上の肥満子宮体癌患者 20 例は非肥 満患者 177 例と比較し、腹腔鏡下子宮体癌手術に おいて術中出血量が増加したが、手術時間や摘出 リンパ節個数、術後在院日数に有意差は認めなか ったと報告している。当院の検討でも肥満症例と 非肥満症例における術中出血量や術後在院日数に 有意差は認めなかった。しかし一方で、当院の検 討ではPLN $(+)$ 群において肥満症例は非肥満症 例に比較し有意に手術時間が延長していた。この 
表3. PLN (+) 群における手術成績術, 術後治療, 治療予後

\begin{tabular}{|c|c|c|c|}
\hline & 非肥満症例 $(n=54)$ & 肥满症例( $n=21)$ & P值 \\
\hline 手術時間(分) & $257.5(170-758)$ & $293(198-480)$ & 0.005 \\
\hline 推定出血量 $(\mathrm{mL})$ & $90(10-690)$ & $125(10-225)$ & n.s \\
\hline 術後入院期問(日) & $5(4-15)$ & $5(4-11)$ & n.s \\
\hline 摘出リンバ節個数(個) & $35(15-75)$ & $51(23-91)$ & 0.003 \\
\hline 術後追加治療 & & & n.s \\
\hline 化学療法 & 7 & 3 & \\
\hline $\begin{array}{c}\text { 傍大動脈リンパ節郭清+ } \\
\text { 大網切除+化学療法 }\end{array}$ & 2 & 1 & \\
\hline なL & 45 & 17 & \\
\hline 再発者数(人) & 1 & 0 & n.s \\
\hline 経過観察期閒(月) & $38.5(23-76)$ & $42(9-65)$ & n.s \\
\hline
\end{tabular}

手術時間, 推定出血量, 術後入院期間, 摘出リンパ節個数, 経過観察期間はいずれも中央值 (最小値-最大值) を示した

表4．術中・術後合併症の合計と内訳

\begin{tabular}{|c|c|c|c|c|c|}
\hline \multirow{3}{*}{ 合計人数 $(\%)$} & \multicolumn{2}{|c|}{ 非肥满症例 $(n=105)$} & \multicolumn{2}{|c|}{ 肥满泟例 $(n=45)$} & \multirow{3}{*}{$\frac{\mathrm{P} \text { 值 }}{\mathrm{n} . \mathrm{s}}$} \\
\hline & \multicolumn{2}{|c|}{$8(7.6)$} & \multicolumn{2}{|c|}{$3(6.7)$} & \\
\hline & $\begin{array}{c}\text { PLN- } \\
(n=51)\end{array}$ & $\begin{array}{c}\text { PLN+ } \\
(n=54)\end{array}$ & $\begin{array}{c}\text { PLN- } \\
(n=24)\end{array}$ & $\begin{array}{c}\text { PLN+ } \\
(n=21)\end{array}$ & \\
\hline 術中输血 & 0 & 0 & 0 & 0 & \\
\hline 術中血菅損伤 & 0 & 1 & 0 & 0 & \\
\hline 術中神経損愎 & 0 & $1^{*}$ & 0 & 0 & \\
\hline 術中尿管損傷 & 0 & $1^{*}$ & 0 & 0 & \\
\hline 骨盤内感染 & 0 & 2 & 1 & 0 & \\
\hline リンパ漏 & 0 & 1 & 0 & 1 & \\
\hline リンパ表腫 & 0 & 0 & 0 & 1 & \\
\hline 㓣䧲開 & 0 & 1 & 0 & 0 & \\
\hline イレウス & 1 & 0 & 0 & 0 & \\
\hline
\end{tabular}

A

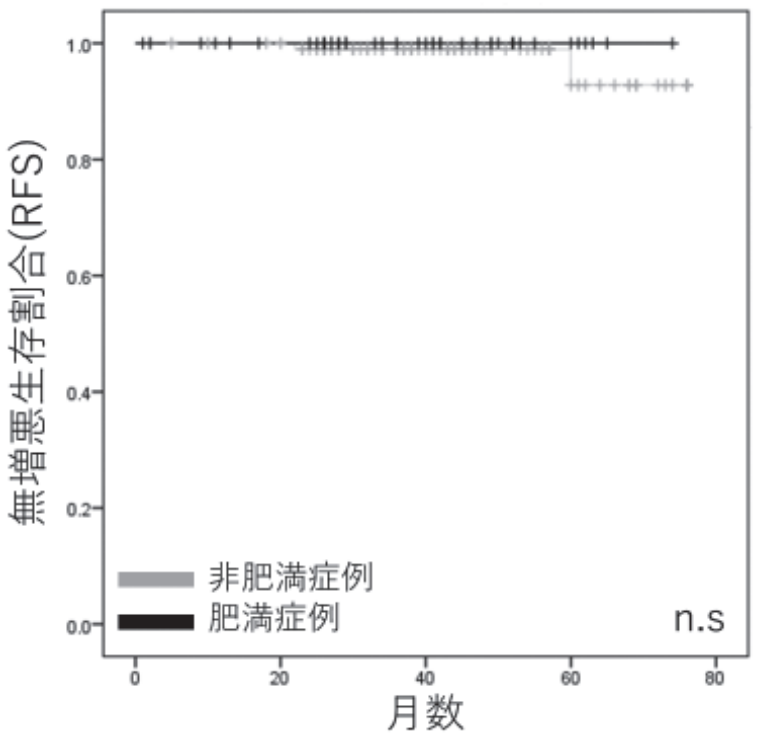

B

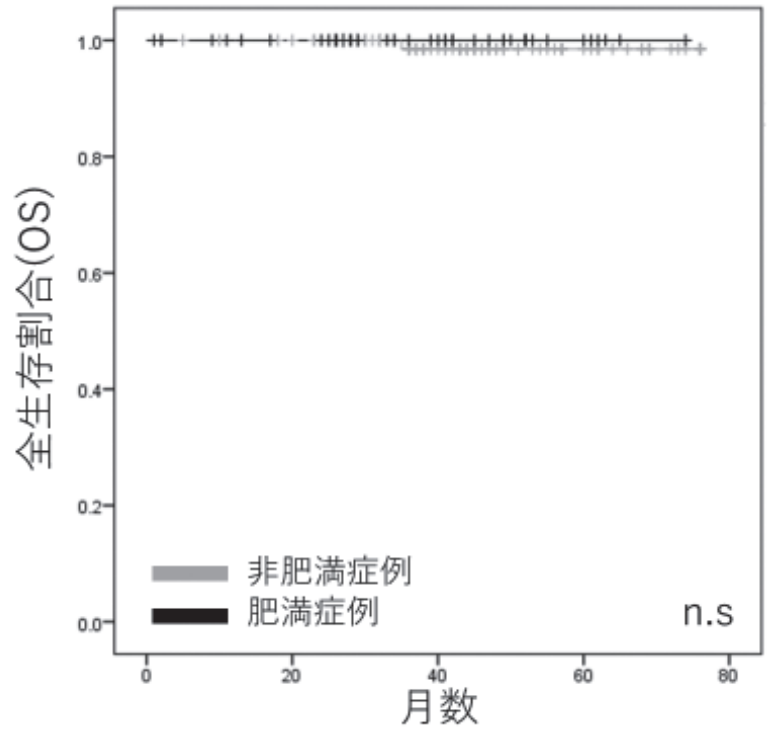

図1。非肥満症例と肥満症例における（A）無増悪生存割合，(B) 全生存割合 
原因としてはPLN (-) 群では手術時間に有意差 を認めないことから、リンパ節郭清に要する手術 時間が延長していることが考えられ、骨盤リンパ 節郭清を行う際に腸管が垂れ込むことなどで視野 の確保が困難となることや、骨盤内の脂肪組織か らの出血を止血する頻度が増すこと、リンパ組織 に付着する脂肪が多く摘出組織量が増えることな どが要因と考えられた。

またBMIが子宮体癌手術の周術期合併症に与え る影響に関するsystematic reviewでは ${ }^{6)}$, BMI $30 \mathrm{~kg} / \mathrm{m}^{2}$ 以上の肥満症例はBMI $30 \mathrm{~kg} / \mathrm{m}^{2}$ 未満の非 肥満症例と比べ開腹手術における創部離開や創部 感染等の周術期合併症の発症率は増加したが、腹 腔鏡下手術ではその発症率に差は認めなかった。 またRudt Sらは7、肥満子宮体癌および子宮内膜 増殖症に対する腹腔鏡下手術での術中および術後 30日以内までの合併症発症率は、BMIによらず 12\%前後であったと報告している。当院での検討 でも非肥満症例と肥満症例間で、腹腔鏡手術にお ける周術期合併症発生の頻度に有意差を認めず、 特に肥満症例でリスクの高いとされる創部離開や 血栓症は一例も認めなかった。また、摘出リンパ 節数に関して諸家の報告では非肥満症例と肥満症 例とで摘出数に差は認めておらず4.5.8)、当院の検 討でも開腹手術における非肥満症例と肥満症例で 摘出リンパ節数に有意差は認めなかったが、腹腔 鏡下手術においては肥満症例で有意に摘出リンパ 節数が増加しており、明らかな要因は不明である ものの、肥満症例であっても非肥満症例と比較し 遜色のないリンパ節郭清が行えていると考えられ た。

本研究の限界としては、第一に他の論文で一般 に肥満の基準とされる BMI $30 \mathrm{~kg} / \mathrm{m}^{2}$ 以上の症例が 少ない点であり、BMI $30 \mathrm{~kg} / \mathrm{m}^{2}$ で非肥満症例と肥 満症例を分け同様の検討を行ったところ、PLN （－）群とPLN (+) 群それぞれで非肥満症例に 比して肥満症例で手術時間の延長や術中出血量の 増加を認め、PLN (+) 群では摘出リンパ節個数 が増加する傾向を示した。両群の術中出血量およ びPLN (+) 群における手術時間の延長や摘出リ ンパ節個数に関してはBMI $25 \mathrm{~kg} / \mathrm{m}^{2}$ 以上を肥満 症例と定義した本検討と比較し同様の傾向であっ たものの、有意差は認めなかった。さらに、他国 でみられるようなBMI $35 \mathrm{~kg} / \mathrm{m}^{2}$ 以上の高度肥満 症例が殆ど含まれていないため、周術期の治療成 績や合併症発症率に有意差を認めないからといっ て、高度肥満症例も含めて本当に腹腔鏡手術が安
全であるかどうか断言できないと考えられる。第 二に、同一の術者が該当症例の 7 割の手術を執刀 している点が挙げられ、この術者の技量により、 肥満症例でも特に対策を講じずとも非肥満症例と 遜色のない治療成績を挙げた可能性は否定できな い。当院における肥満症例への手術時の工夫とし て、トロッカーが頻回に抜けるのを防ぐためにバ ルーン付きのトロッカーを使用する、コンパート メント症候群を防ぐために $2 \sim 3$ 時間毎に体位を 水平に戻し肩や頭部の状態を確認する、などの手 法で手術時間の短縮や術中合併症の予防を行って いる場合もあるが、術者間で対応の差があるのが 実情である。最後に、肥満子宮体癌患者の腹腔鏡 下手術後の長期予後に関して、諸家の報告では非 肥満患者と比較して増悪生存期間と全生存期間に 有意差は認めないとの報告があり ${ }^{4,9)}$ 、我々の検討 でも 5 年程度の経過観察期間内で同様の結果は示 せたが、以降の長期予後を検討するには至らなか った。

しかしながら本研究は、高度肥満女性自体が他 国に比べ国内にさほど多くないことを考慮すれ ば、日本における肥満子宮体癌患者の腹腔鏡手術 に拀ける治療成績を示した一つの研究として非常 に意義があると考える。2014年に保険収載された 腹腔鏡下子宮体癌手術であるが、依然肥満症例に 対しては開腹手術を選択する施設も少なくないと 考えられる。

今回の研究結果により、肥満症例であっても非 肥満症例にほぼ遜色なく治療を行えることが示さ れたため、この結果が国内の各施設での肥満症例 への腹腔鏡手術の実施の推進を鼓舞する一端とな れればと考える。現在当院では複数の医師が腹腔 鏡下子宮体癌手術の執刀を行うようになってお り、今後さらに症例の蓄積を重ね、周術期の治療 成績および長期予後に関して検討を行いたい。

\section{【結 語】}

早期子宮体癌に対する腹腔鏡下子宮体癌手術に おいて、骨盤リンパ節郭清施行症例では非肥満症 例に比べ肥満症例で手術時間が延長することが示 唆された。しかし、術中出血量や術後入院日数、 周術期合併症発生率に差は認められず、肥満症例 は非肥満症例と比較して遜色なく安全に手術が施 行可能であると考えられた。

本論文の要旨は第 57 回日本産科婦人科内視鏡学 会学術講演会において発表した。 


\section{参考文献}

1) Anthony J. Senagore, Conor P. Delaney, Khaled Madboulay, et al.: Laparoscopic Colectomy in Obese and Nonobese Patients. J Gastrointest Surg.J 2003; 7(4): 558-561.

2 ）日本肥満学会: 肥満症診療ガイドライン 2016 http://www.jasso.or.jp/contents/magazine/journal. $h t m l($ 最終アクセス日2019年6月28日)

3 ）日本臨床腫瘍研究グループ: CTCAE Version4.0 日本 語訳

4 ) Min-Hyun Baek, Shin-Wha Lee, Jeong-Yeol Park, et al.: Feasibility and Safety of Laparoscopic Surgery for Obese Korean Women with Endometrial Cancer: Long-Term Results at a Single Institution. J Korean Med Sci 2014; 29: 1536-1543.

5 ) 寺井義人, 橋田宗祐, 芦原敬允. 他: 肥満子宮体がんに 対する腹腔鏡下手術の安全性評価の検討. 産婦手術 2017; 28: 68-72.

6 ) Frederique Bouwman, Anke Smits, Alberto Lopes, et al: The impact of BMI on surgical complications and outcomes in endometrial cancer surgery-An institutional study and systematic review of the literature. Gynecol Oncol 2015; 139: 369-376.

7 ) Rudt S.Suidan, Weiguo He, Charlotte C.Sun et al.: Impact of body mass index and operative approach on surgical morbidity and costs in women with endometrial carcinoma and hyperplasia. Gynecol Oncol 2017; 145: 55-60.

8) Dennis R.Scribner, Jr, Joan L.Walker, Gary A.Johnson et al:: Laparoscopic Pelvic and Paraaortic Lymph Node Dissection in the Obese. Gynecol Oncol 2002; 84: 426-430.

9 ) A. Farthing, J. C hatterjee, P. J oglekar-Pai et al.: Total laparoscopic hysterectomy for early stage endometrial cancer in obese and morbidly obese women. J Obstet Gynaecol 2012; 32: 580-584.

投稿日：2019年 4 月17日

採択日：2019年10月 1 日 